\title{
Checklist of benthic macroinvertebrates of the Lago Pratignano (northern Apennines, Italy): an extremely rich ecosystem
}

\author{
Ivano Ansaloni, Daniela Prevedelli, Matteo Ruocco* and Roberto Simonini \\ University of Modena and Reggio Emilia, Department of Life Sciences, via Campi 213/d, 41125 Modena (MO), Italy \\ * Corresponding authors. E-mail: matteo.ruocco@unimore.it
}

\begin{abstract}
A checklist of the macroinvertebrates fauna of the Lago Pratignano is presented here. The Lago Pratignano is a small, natural water body of the high (1,307 $\mathrm{m}$ above sea level) Northern Apennines, Italy. It represents an important site for the conservation of endangered flora and amphibians, and its importance for the conservation of the macroinvertebrate fauna is highlighted. The 82 taxa recorded make it an extremely rich habitat. The most represented group was Diptera, with 31 taxa, followed by Coleoptera, with nine, and Oligochaeta and Arachnida, each with eight taxa. Other groups are present in lower numbers. Despite the scant attention to theP study of the macroinvertebrates of small lentic habitats in the Northern Apennines, their importance for the conservation of the invertebrate fauna and the high contribution they give to the biodiversity is highlighted here.
\end{abstract}

Key words: biodiversity; ponds; macrozoobenthos community; Parco del Frignano; Modena

\section{INTRODUCTION}

Ponds offer a wide variety of habitats (Davies et al. 2008), represent important hotspots for biodiversity (EPCN 2008), and compared to all other water body types, they support more unique and rare species (Williams et al. 2004). These ecosystems contribute significantly to biological diversity (Ruggiero et al. 2005); altogether, they host a larger number of species than rivers, lakes or streams (Williams et al. 2004). Despite their high ecological value, they are nowadays the most vulnerable and threatened water ecosystems, yet they still receive scant attention in political and legislative spheres (EPCN 2008). The macroinvertebrate community contributes to this biodiversity with its species playing essential roles in different key processes of these ecosystems (Reice and Wohlenberg 1993). Therefore, they have been chosen by the Directive
2000/60/EC (Water Framework Directive) as indicators of the ecological status of waterbodies (CEC 2005).

Local and national authorities protect most of the mountain areas along the Apennines in Italy, but the few natural ponds are still under threat even if they are within natural parks (Solimini et al. 2008). Some information on the macrozoobethic community of small water bodies is present for Europe (Boix et al. 2001; Sahuquillo et al. 2007; Oertli et al. 2008; Céréghino et al. 2012; Guareschi et al. 2012; Novikmec et al. 2015). In Italy, there are data for alpine mountains ponds (Boggero et al. 2005; Boggero and Lencioni 2006; Füreder et al. 2006; Maiolini et al. 2006; Steingruber et al. 2013) and for lowland ponds (Solimini et al. 2005; Della Bella et al. 2005; Della Bella and Mancini 2009). However, only scattered information is available for the central Apennines Mountains (Solimini et al. 2008) and none for the northern and southern parts. The northern part of the Apennines is located between two different phytogeographic regions: the Euro-Siberian region to the north and the Mediterranean region to the south (Alessandrini et al. 2003). This area at the boundary between two different phytogeographic regions should be investigated: high-altitude aquatic ecosystems may be more sensitive to global climate change than aquatic ecosystems at lower elevations (Theurillat and Guisan 2001) and could be more quickly affected by climate change.

As at the national level, data on these water bodies in the province of Modena are scattered. There are several publications on the macroinvertebrates of the lowlands (Ansaloni and Prevedelli 2008; Ansaloni et al. 2009, 2010, 2014) but none on the macroinvertebrates of the high Apennines. Only studies on plankton (Moroni 1962), vegetation (Accorsi et al. 1981), amphibians (Sala et al. 1996), physico-chemical parameters of the waters (Boraldi et al. 2005) and single groups of macroinvertebrates (Rocchi 2009) are available.

The importance of the Lago Pratignano for the 
richness and the peculiarity at a regional scale level of its flora and fauna has already been highlighted by Accorsi et al. (1982), Mazzoldi et al. (2009) and Alessandrini et al. (2010). However, no studies on the macroinvertebrate community of this pond have been published. The aim of this paper is to highlight the richness of the macroinvervetebrate community in this pond, to show seasonal variations, and to create a baseline of information for the conservation and the possible future management of this valuable habitat. Furthermore, this study adds to the basic knowledge on these habitats, which are still barely known in the northern Apennines.

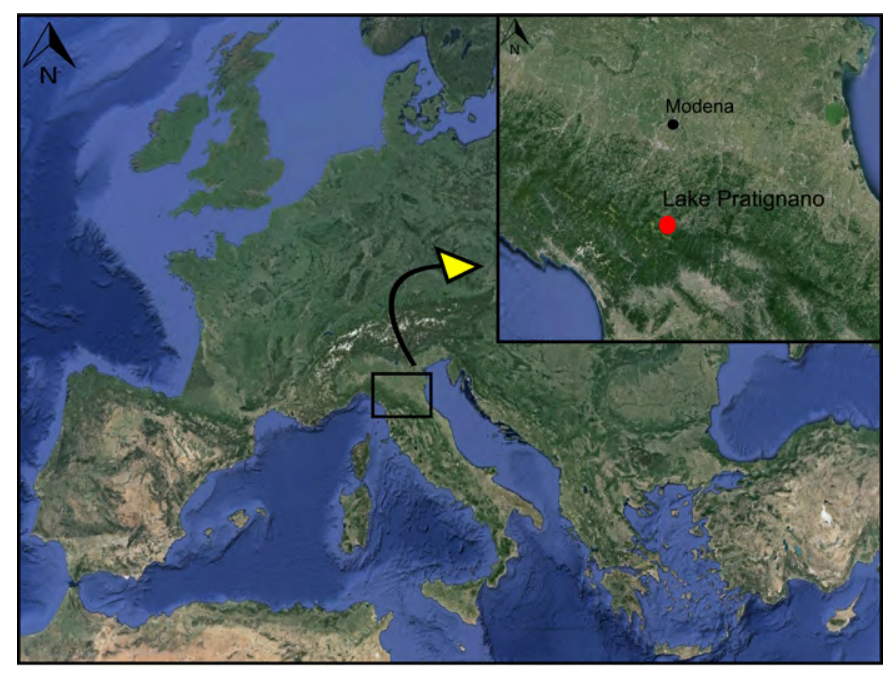

Figure 1. Map of the study area (modified after Google Earth ${ }^{\text {TM }}$ Pro 7.1.5.1557).

\section{MATERIALS AND METHODS \\ Study site}

The Lago Pratignano ( $44^{\circ} 12^{\prime} 39^{\prime \prime} \mathrm{N}, 010^{\circ} 43^{\prime} 30^{\prime \prime} \mathrm{E}$ ) is a small, high-altitude water body located at $1,307 \mathrm{~m}$ above sea level within the Regional Park of the High Modena Appenines (Parco Regionale dell'Alto Appennino Modenese, Northen Apennines, Italy) and the SCI-SPA IT4040001 "Cimone, Libro Aperto, Lago di Pratignano" of the Natura 2000 network (Figure 1). The Lago Pratignano has a total surface area of about $50,000 \mathrm{~m}^{2}$; the mean depth is about $2 \mathrm{~m}$ and the maximum depth is $4.5 \mathrm{~m}$. Through the year, the water level varies by about $0.4 \mathrm{~m}$. Considering its dimensions and its mean depth, it can be defined as a pond according to the European Pond Conservation Network (EPCN 2008). The pond has a semi-triangular outline that is elongated on a northsouth axis. One small tributary flows into the pond at its southern edge and there is no outflow (Figure 2). The presence of water is guaranteed by a broad catchment basin, by the permeability of the surrounding ground and by the presence of a thick covering of ice from December through to the end of March to April. Other morphometric and geological information of the area can be found in Bertacchini et al. (1999). According to Kottek et al. (2006), the climate of the area of the Lago Pratignano is warm temperate and fully humid with warm summers ( $\mathrm{Cfb}$ type following the Köppen-Geiger climate classification).

Different vegetation typologies are present within the pond (Figure 3). In the southern part, where the pond is deepest, the vegetation is characterized by the presence of the hydrophytes: Potamogeton natans, $P$. oblongus, $P$. trichoides and Myriophyllum spicatum. Near the shore, where the depth is less than $1 \mathrm{~m}$, Potamogeton sp., Sparganium emersum and Ranunculus trichophyllus subsp. trichophyllus are present. The vegetation in the shallows (water $0.8-1 \mathrm{~m}$ deep) is characterized by
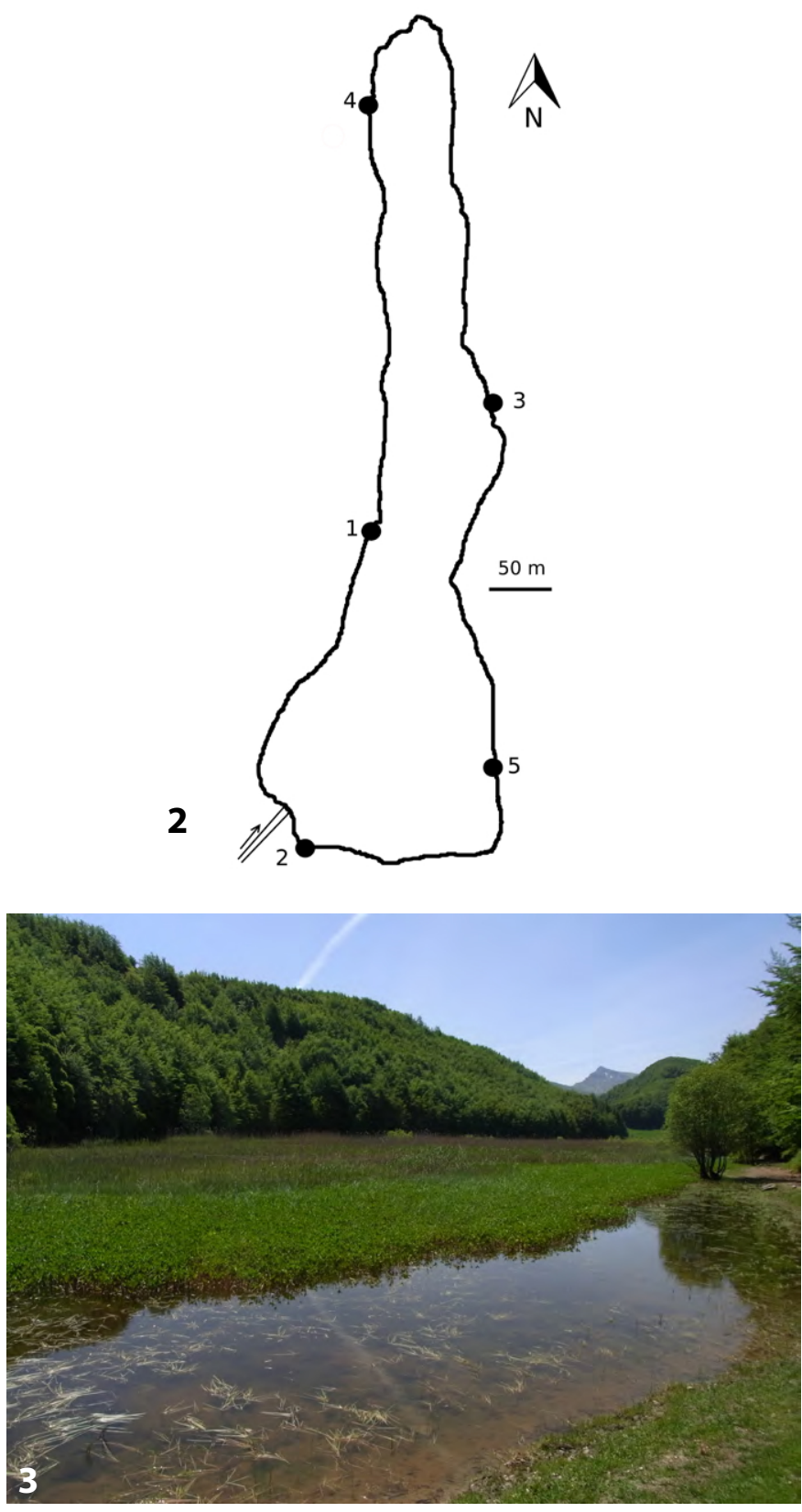

Figures 2 and 3. The pond Lago Pratignano. 2: Map of the Lago Pratignano showing the location of the sampling stations. 3: View of the pond from sampling station 5 . 
concentric belts of Menyanthes trifoliata, Carex rostrata and Carex versicaria (from deepest to shallow water). At the margins, a discontinuous formation of Alopercurus aequalis, Eleocharis palustris, Oenanthe acquatica and Hottonia palustris is present. Finally, there is a peat bog and associated vegetation that is located at the north end of the pond where, among Menyanthes trifoliata and Phragmites australis, there is a wide floating pillow of Sphagnum cuspidatum and Sphagnum sp. It is there that Drosera rotundifolia, Utricularia australis and U. vulgaris (Alessandrini et al. 2010), three interesting species for the Italian flora, can be found.

\section{Data collection}

The sampling of macrozoobenthos was performed in spring, summer and autumn 1999 and in summer 2006. All ice-free seasons were sampled to detect possible differences and to record all the biodiversity present in the pond. No samples were taken during winter because of ice on the pond. The summer sampling was repeated in 2006 as it resulted that the biodiversity was richest in that season after the first campaign of 1999. Five sampling sites (St. 1, St. 2, St. 3, St. 4 and St. 5) were selected to cover all the different substrates and littoral vegetation types (Figure 2). Station 4 was sampled only in spring 1999 because this area dried during the summer of 1999 and 2006 and autumn of 1999; station 2 was not sampled in autumn of 1999 for the same reason. The relative dominance of the different substrates and littoral vegetation types were considered so as to equally distribute the sampling effort over all habitat types. No quantitative samples could be taken because of the variability of the substrate (from mud to sand and from organic deposits to submerged grassland) and because of the presence of the submerged vegetation that could be sampled only with a dip net.

At each sampling site the main physico-chemical parameters were recorded seasonally. Data included water temperature, $\mathrm{pH}$, conductivity, dissolved oxygen and percent oxygen saturation that were recorded by a portable instrument.

Zoobenthos samples were taken from the littoral zone to a maximum depth of $0.5 \mathrm{~m}$ using a dip net $(25 \times 25 \mathrm{~cm}$ wide; $250 \mu \mathrm{m}$ mesh size) according to Storey et al. (1991). Collections were made under permit (Prot. n. 677) from the Director of the Regional Park of the High Modena
Appenines. Specimens were preserved in 5\% formalin. In the laboratory, animals were processed through a series of sieves (5, 2, 1 and $0.5 \mathrm{~mm}$ mesh size), preserved in $70 \%$ ethanol and then sorted. Hydrachnidia were preserved in Koenike's fluid, clarified in Andre's fluid and mounted in Hoyer's medium for identification. The identification took place under a stereomicroscope or a microscope to the lowest possible taxonomic level. The word taxa was used in the results and discussion paragraphs to relate different groups to the lowest taxonomic level.

The identification of Leptolida was based on the Campbell (1989) classification. The identification of other taxa were based on keys provided by Girod et al. (1980; Mollusca), Brinkhurst and Jamieson (1971; Oligochaeta), Minelli (1977; Irudinea), Argano (1979; Isopoda), Carchini (1983; Odonata), Belfiore (1983; Ephemeroptera), Consiglio (1980; Plecoptera), Tamanini (1979; Heteroptera), Franciscolo (1979; Coleoptera), Moretti (1983; Trichoptera), Campaioli et al. (1999; Lepidoptera), Rivosecchi (1984; Diptera Ceratopogonidae and Chaoboridae), Nocentini (1985; Diptera Chironominae), and Ferrarese (1983; Diptera Tanypodinae), Rossaro (1982; Diptera Orthocladiinae). The identification of Hydrachnidia was based mainly on Viets (1936) and Lundblad (1967). The nomenclature was uniformed and updated following Fauna Europea (de Jong et al. 2014).

All the identified material is available for study as alcohol-preserved samples or permanent slide collections in the Department of Life Sciences at the University of Modena and Reggio Emilia.

\section{RESULTS}

The values of the measured physico-chemical parameters are shown in Table 1 . The strongest variations were found in water temperature. It ranged from $4.5^{\circ} \mathrm{C}$ in spring 1999 at site 1 , to $20.5^{\circ} \mathrm{C}$ at site 2 in summer 2006. Oxygen had low concentration but presented seasonal variations: its maximum value was reached in spring 1999 with $8 \mathrm{mg} \cdot \mathrm{l}^{-1}$ (site 4 ) and a saturation of $80 \%$ at site 4 ; its minimum value was reached in summer 2006 when the oxygen concentration was $0.4 \mathrm{mg} \mathrm{l}^{-1}$ at site 5 with a saturation of $6 \%$. The $\mathrm{pH}$ values resulted relatively homogeneous, both in space and time. The maximum value of 7.16 was recorded at site 4 in spring 1999 and minimum of 5.18 recorded at site 1 in summer 1999 .

Table 1. Physico-chemical parameters of the pond Lago Pratignano recorded during the samplings.

\begin{tabular}{|c|c|c|c|c|c|c|c|c|c|c|c|c|c|c|c|c|}
\hline & \multicolumn{5}{|c|}{ Spring 1999} & \multicolumn{4}{|c|}{ Summer 1999} & \multicolumn{3}{|c|}{ Autumn 1999} & \multicolumn{4}{|c|}{ Summer 2006} \\
\hline & St. 1 & St. 2 & St. 3 & St. 4 & St. 5 & St. 1 & St. 2 & St. 3 & St. 5 & St. 1 & St. 3 & St. 5 & St. 1 & St. 2 & St. 3 & St. 5 \\
\hline Temperature $\left[{ }^{\circ} \mathrm{C}\right]$ & 14.40 & 14.50 & 13.90 & 13.40 & 14.30 & 19.20 & 19.00 & 17.70 & 19.20 & 4.50 & 5.90 & 7.10 & 17.50 & 20.50 & 18.50 & 19.60 \\
\hline Dissolved oxygen $\left[\mathrm{mg} \cdot{ }^{-1}\right]$ & 4.00 & 3.70 & 2.50 & 8.00 & 5.40 & 4.00 & 4.80 & 1.40 & 5.40 & 5.50 & 4.30 & 3.90 & 1.30 & 2.80 & 0.60 & 0.40 \\
\hline Dissolved oxygen sat. [\%] & 42.00 & 37.00 & 25.00 & 80.00 & 31.00 & 45.00 & 49.00 & 18.00 & 60.00 & 47.00 & 41.00 & 35.00 & 18.00 & 43.00 & 9.00 & 6.00 \\
\hline $\mathrm{pH}$ & 6.30 & 7.10 & 6.50 & 7.16 & 7.10 & 5.18 & 6.10 & 6.30 & 6.50 & 6.30 & 7.20 & 6.40 & 5.44 & 5.82 & 5.93 & 6.17 \\
\hline Conductivity $\left[\mu \mathrm{S} \cdot \mathrm{cm}^{-1}\right]$ & 73.00 & 75.00 & 75.00 & 45.00 & 70.00 & 67.00 & 62.00 & 58.00 & 58.00 & 65.00 & 36.00 & 45.00 & 61.40 & 68.60 & 107.70 & 69.60 \\
\hline
\end{tabular}




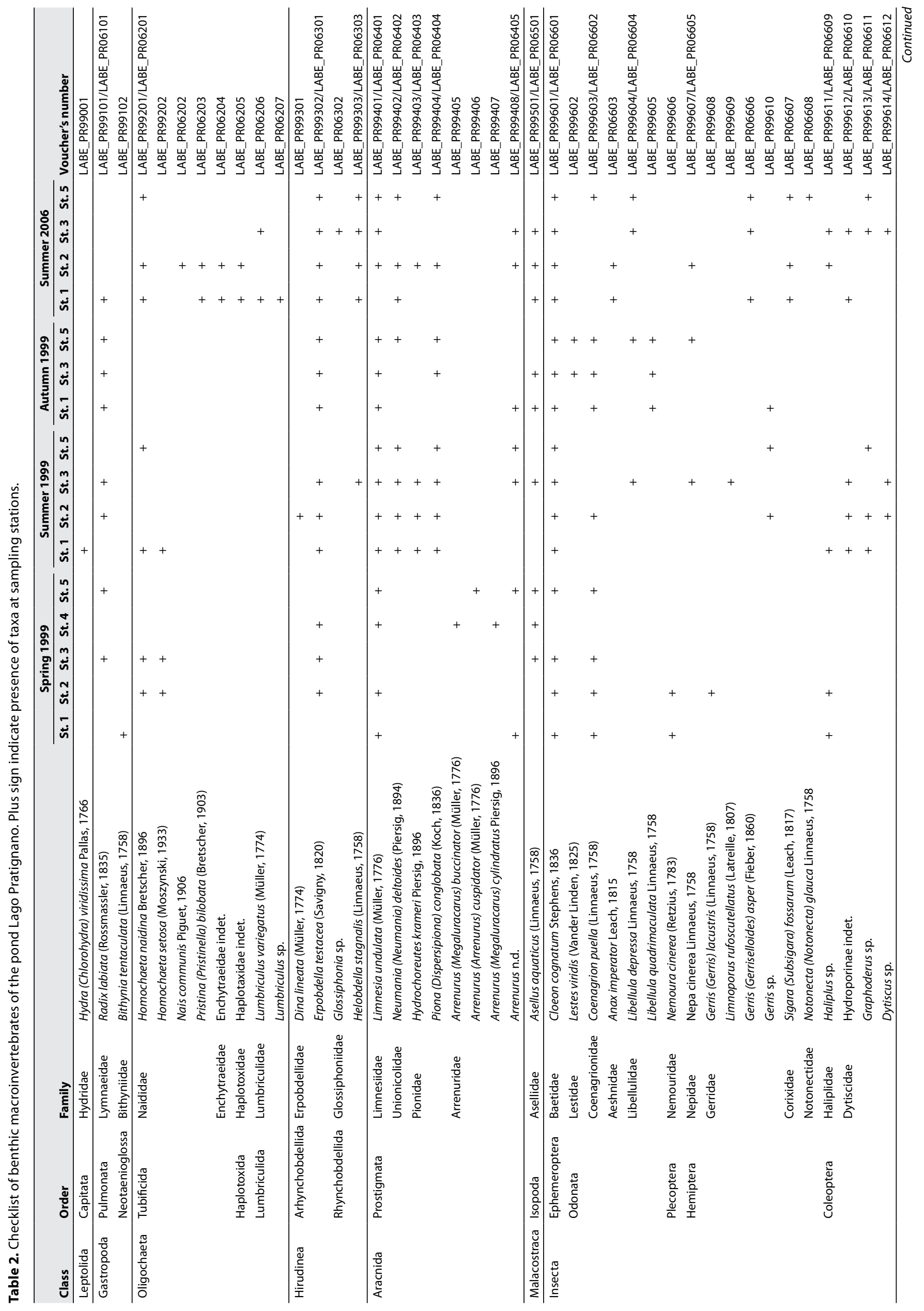




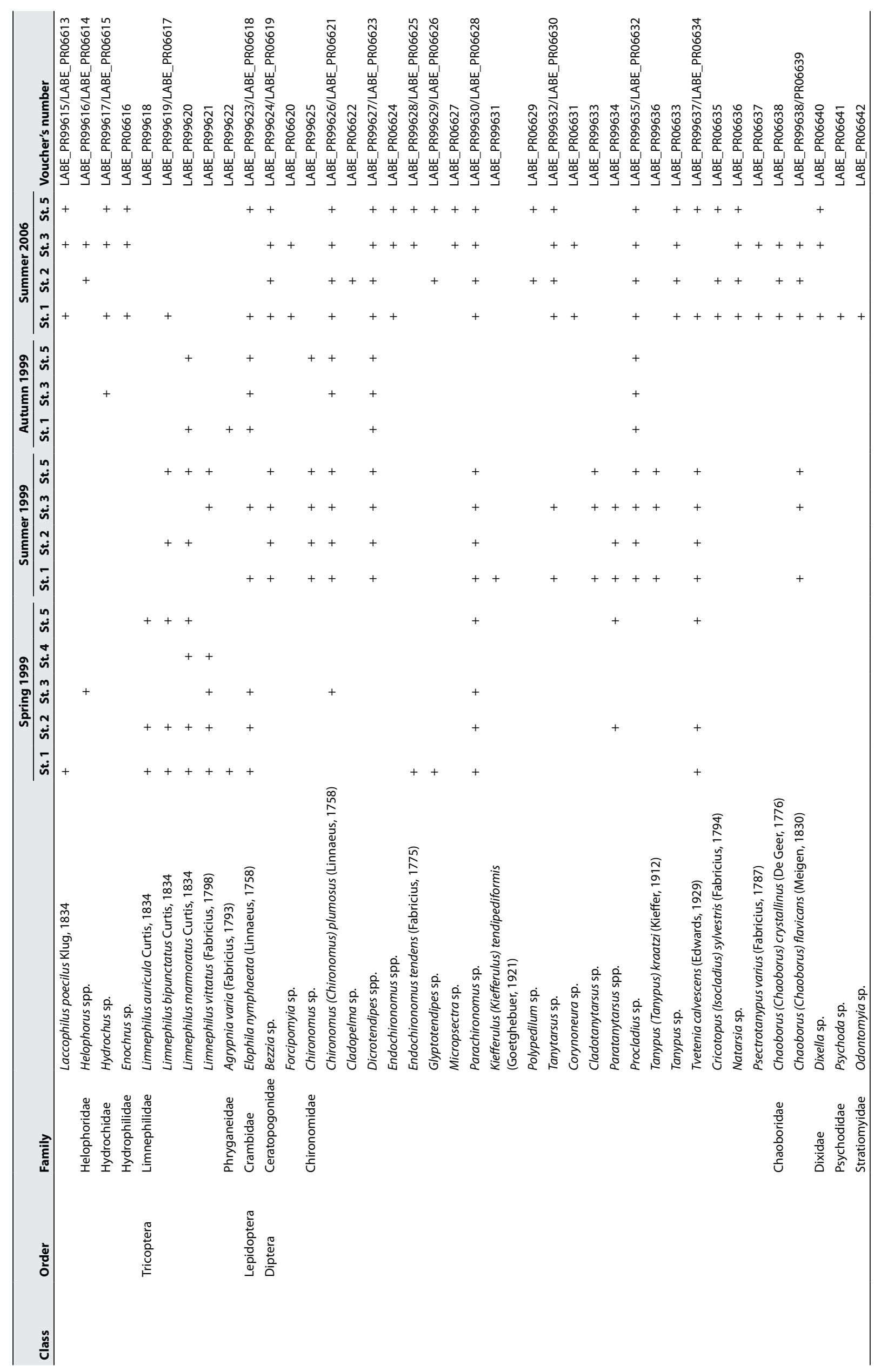


Conductivity ranged from $107.70 \mu \mathrm{cm}^{-1}$ and $36.00 \mu \mathrm{S}$ $\mathrm{cm}^{-1}$ evidencing a gradual decreasing of the values from spring to autumn in all the sampling sites.

A total of 82 different taxa divided in four phyla, belonging to seven classes, 18 orders and 39 families (Table 2) were recorded during the samplings. The richest group was Diptera with 31 taxa, followed by Coleoptera with nine taxa, Oligochaeta and Arachnida with eight taxa. Odonata and Trichoptera were represented by five taxa, Hirudinea by four, Gastropoda by two and Malacostraca, Ephemeroptera, Plecoptera and Leptolida were each represented by one taxon.

During the spring of 1999, 31 taxa were recorded, 40 taxa were recorded during the summer of 1999, while 22 taxa during autumn 1999. In summer 2006, a total of 59 taxa were found. Summer resulted the most reach season in terms of biodiversity collected.

Taxa found both in 1999 and 2006 were 33, while 23 were exclusively recorded only in 1999 and 26 were exclusively recorded in 2006. Differences have been recorded between the 1999 and summer 2006 samples (Table 1) when taxa not previously recorded were found: Oligochaeta (Nais communis Piguet 1906, Pristina (Pristinella) bilobata (Bretscher, 1903), Enchytraeidae indet., Haplotaxidae indet. and Lumbriculus variegatus (Müller, 1774)), the Diptera Forcipomyia sp., Cladopelma sp., Micropsectra sp., Polypedilum sp., Corynoneura sp., Cricotopus (Isocladius) sylvestris (Fabricius, 1794), Natarsia sp., Psectrotanypus varius (Fabricius, 1787), Chaoborus (Chaoborus) crystallinus (De Geer, 1776), Psychoda sp. and other insects as Gerris (Gerriselloides) asper (Fieber, 1860), Sigara (Subsigara) fossarum (Leach, 1817), Notonecta (Notonecta) glauca Linnaeus, 1758 and Enochrus sp. On the other hand, in 2006 the presence of Hydra (Chlorohydra) viridissima were not confirmed, together with the Odonata Lestes viridis (Vander Linden, 1825) and Libellula quadrimaculata Linnaeus, 1758, the Plecoptera Nemoura cinerea (Retzius, 1783) some Hemiptera and the most part of Tricoptera (Table 2). The dipterans Cladotanytarsus sp. and Paratanytarsus spp. were not reconfirmed, as was a Dicrotendipes sp. attributable to the lobiger group. Finally, only two species of gastropods were recorded, Radix labiata (Rossmässler, 1835) and Bithynia tentaculata (Linnaeus, 1758), despite the prominence of this group in aquatic plants.

\section{DISCUSSION}

This contribution to the invertebrate macrofauna of a pond in the northern high Apennines is a first attempt to fill a gap in our knowledge. The high number of taxa identified (82) confirms the importance of the Lago Pratignano for macroinvertebrate biodiveristy in the province of Modena and in the northern Apennines.

Comparing the results with other European systems, the Lago Pratignano was found to be extremely rich in the number of taxa (Boix et al. 2001; Sahuquillo et al. 2007; Oertli et al. 2008; Céréghino et al. 2012; Guareschi et al. 2012; Novikmec et al. 2015); at the same time, comparisons of the results with high-altitude habitats in the Alps (Boggero et al. 2005; Boggero and Lencioni 2006; Steingruber et al. 2013) and in the central part of the Apennines, where Solimini et al. (2008) found 61 taxa in a total of 31 ponds, highlight the richness of Lago Pratignano. These results confirm that the northern Apennines could represent an important area for further in-depth investigations of the macroinvertebrate communities of ponds. Moreover, comparison of Coleoptera from Lago Pratignano to a publication by Mazzoldi et al. (2009) found diversity (30 species) to be greater in this study; two species of Dytiscidae are extremely interesting for their rarity and some individuals belonging to the genus Helophorus are now under further study because they could represent a new endemic taxon (Mazzoldi et al. 2009). The possible presence of Dicrotendipes lobiger in this study should be further investigated because it is a species that is typical of central and northern Europe and alpine region. There is only one station in the central Apennines, and so, it could be considered as a glacial relict (Nocentini 1985).

Unfortunately, no data are available for other ponds of the same region and no comparisons can be made, but from this first list of species it resulted clear that more effort should be made in studying these systems. The climate of the region, the geographic localization and the low human impact on the area could contribute to the richness and peculiarity of the Lago Pratignano, but without additional data only a hypothesis can be done.

Annual differences in meteorological conditions and a globally changing climate can affect the flora and fauna, and in particular, animals with short life cycles as are typical of most macroinvertebrates. The higher number of taxa in summer compared to spring and autumn is easily ascribable to the region's climate. Differences between 1999 and 2006 are also attributable to the periodicity of some groups: the plecopteran Nemoura cinerea and the odonate Libellula quadrimaculata, for example, are typically found in spring and rarely in summer. Finally, the low diversity of gastropods could be correlated with the physico-chemical properties of the water and in particular with the relatively low $\mathrm{pH}$. In fact, the values recorded during the samplings vary from 5.18 to 7.16 (Table 1) which are values typically obtained from peat bog habitats (Minelli 2004). Low $\mathrm{pH}$ values such as these are not ideal for these organisms.

In conclusion, the contribution of the macroinvertebrate community of high altitude aquatic habitats in the northern Apennines to the biodiversity is here highlighted. The Lago Pratignano resulted to be important not only for its particularly interesting flora and amphibian fauna but also for its rich macroinvertebrate 
community. The data presented here will be useful in the future to understand the natural transformations of this habitat and the possible alterations caused by the climate change. Furthermore, this work represents a starting point for the study on much-neglected pond habitats in the northern Apennines.

\section{ACKNOWLEDGEMENTS}

We thank Prof. Marisa Mari and Prof. Ivano Morselli helping with determination of Arachnida.

\section{LITERATURE CITED}

Accorsi, C.A., M. Bandini Mazzanti, D. Bertolani Marchetti, M. Bertolani, L. Boni, G. Braggio, G. Ciuff, T. De Cunzo, C. Ferrari, M. Guido, C. Montanari and P. Paoli. 1981. Ricerche geobotaniche al Lago di Pratignano (Fanano Modena); pp. 73-199 in: L'alta Valle del Panaro, II, 64 . Modena: Deputazione di Storia Patria per le Antiche Provincie Modenesi.

Alessandrini, A., B. Foggi, G. Rossi and M. Tomaselli. 2003. Flora di altitudine dell'Alto Appennino tosco-emiliano. Bologna: Tipografia Moderna Industrie Grafiche. 329 pp.

Alessandrini, A., L. Delfini, P. Ferrari, F. Fiandri, M. Gualmini, U. Lodesani and C. Santini. 2010. Flora del Modenese: censimento, analisi, tutela. Regione Emilia-Romagna: Istituto Beni Culturali. $415 \mathrm{pp}$.

Ansaloni, I. and D. Prevedelli. 2008. La comunità macrozoobentonica di alcune zone umide del Modenese: I — Il lagoo-canale del giardino storico di Villa Sorra (Comune di Castelfranco Emilia). Atti della Società dei Naturalisti e Matematici di Modena 139: 75-87.

Ansaloni, I., M. Iotti, C. Sammarini and R. Simonini. 2008. La comunità macrozoobentonica di alcune zone umide del modenese: II - Oasi naturalistica "La Francesa"(Comune di Carpi). Atti della Società dei Naturalisti e Matematici di Modena 139: 89-100.

Ansaloni, I., P. Artioli and R. Simonini. 2009. La comunità macrozoobentonica di alcune zone umide del modenese: III "Valli le Partite" (Comune di Mirandola). Atti della Società dei Naturalisti e Matematici di Modena 140: 153-165.

Ansaloni, I., F. Grenzi, A. M. Manzieri and R. Simonini. 2010. La comunità macrozoobentonica di alcune zone umide del modenese: IV - "Area di riequilibrio ecologico del fontanile di Montalee" (Comune di Castelnuovo Rangone, provincia di Modena). Atti della Società dei Naturalisti e Matematici di Modena 141: 139-152.

Ansaloni, I., J. Magnani, A. M. Manzieri and L. Sala. 2014. Il Sito Natura 2000 "Il Torrazzuolo" (Nonantola, Modena): comunità macrozoobentonica e considerazioni ecologiche. Atti della Società dei Naturalisti e Matematici di Modena 145: 128-218.

Argano, R. 1979. Isopodi (Crustacea Isopoda). Guide per il riconoscimento delle specie animali delle acque interne italiane. 5. Italy: Consiglio Nazionale per le Ricerche. $62 \mathrm{pp}$.

Belfiore, C. 1983. Efemerotteri (Ephemeroptera). Guide per il riconoscimento delle specie animali delle acque interne italiane. 24 Italy: Consiglio Nazionale per le Ricerche. $112 \mathrm{pp}$.

Bertacchini, M., C. Giusti, M. Marchetti, M. Panizza and M. Pellegrini. 1999. I Beni Geologici della Provincia di Modena. Modena: Artioli. 104 pp.

Boix, D., J. Sala and R. Moreno-Amich. 2001. The faunal composition of Espolla Pond (NE Iberian Peninsula): the neglected biodiversity of temporary waters. Wetlands 21(4): 577-592. doi: 10.1672/0277-5212(2001)021

Boggero, A., A. Marchetto, M. Manca, R. Mosello and G.A. Tartari. 2005. Studies on small mountain lakes in the Val Grande National Park (Central Alps, Italy). Studi Trentini di Scienze Naturali, Acta Biologica 82: 43-54.
Boggero, A. and V. Lencioni. 2006. Macroinvertebrates assemblages of high altitude lakes, inlets and outlets in the southern Alps. Archiv für Hydrobiologie 165(1): 37-61. doi: 10.1127/00039136/2006/0165-0037

Boraldi, V., A. M. Manzieri and F. Mantelli. 2005. Stato di qualità ambientale dei laghi dell'Alto Appennino Modenese. Modena: Agenzia RegionalePrevenzione e Ambiente. 52 pp.

Brinkhurst, R.O. and B. G. M. Jamieson. 1971. Aquatic Oligochaeta of the world. Edinburgh: Oliver \& Boyd. 86o pp.

Campbell, R.D. 1989. Taxonomy of European Hydra (Cnidaria: Hydrozoa): a re-examination of its with emphasis on the species $H$. vulgaris Pallas, $H$. attenuata Pallas and $H$. circumcincta Schulze. Zoological Journal of the Linnean Society 95: 219-244. doi: 10.1111/j.1096-3642.1998.tbo1992.x

Carchini, G. 1983. Odonati (Odonata). Guide per il riconoscimento delle specie animali delle acque interne italiane. 21. Italy: Consiglio Nazionale per le Ricerche. 79 pp.

Campaioli, S., P. F. Ghetti, A. Minelli and S. Ruffo. 1999. Manuale per il riconoscimento dei Macroinvertebrati delle acque dolci italiane, Provincia Autonoma di Trento, II: 127 pp.

CEC. 2005. Common implementation strategy for the Water Framework Directive (2000/6o/EC). Guidance document N12. Horizontal guidance on the role of wetlands in the Water Framework Directive, 17th December 2003. Official Journal of European Communities, Luxembourg.

Céréghino, R., B. Oertli, M. Bazzanti, C. Coccia, A. Compin, J. Biggs, N. Bressi, P. Grillas, A. Hull, T. Kalettka and O. Scher. 2012. Biological traits of european pond macroinvertebrates. Hydrobiologia 689(1): 51-61. doi: 10.1007/s10750-011-0744-y

Consiglio, C. 1980. Plecotteri (Plecoptera). Guide per il riconoscimento delle specie animali delle acque interne italiane. 9. Italy: Consiglio Nazionale per le Ricerche. $67 \mathrm{pp}$.

Davies, B. R., J. Biggs, P. J. Williams, J. T. Lee and S. Thompson. 2008. A comparison of the catchment sizes of rivers, streams, ponds, ditches and lakes: implications for protecting aquatic biodiversity in an agricultural landscape. Hydrobiologia 597(1): 7-17. doi: 10.1007/s10750-007-9227-6

Della Bella, V., M. Bazzanti and F. Chiarotti. 2005. Macroinvertebrate diversity and conservation status of Mediterranean ponds in Italy: water permanence and mesohabitat influence. Aquatic Conservation: Marine and Freshwater Ecosystems 15(6): 5836oo. doi: 10.1002 aqc.743

Della Bella, V. and L. Mancini. 2009. Freshwater diatom and macroinvertebrate diversity of coastal permanent ponds along a gradient of human impact in a Mediterranean Eco-Region. Hydrobiologia 634(1): 25-41. doi: 10.1007/s10750-009-9890-X

de Jong, Y., M. Verbeek, V. Michelsen, P. de Place Bjørn, W. Los, F. Steeman, N. Bailly, C. Basire, P. Chylarecki, E. Stloukal, G. Hagedorn, F. T. Wetzel, F. Glöckler, A. Kroupa, G. Korb, A. Hoffmann, C. Häuser, A. Kohlbecker, A. Müller, A. Güntsch, P. Stoev and L. Penev. 2014. Fauna Europaea - all European animal species on the web. Biodiversity Data Journal 2: e4034. doi: 10.3897/BDJ.2.e4034

EPCN (European Pond Conservation Network). 2008. The pond manifesto. Available: http://campus.hesge.ch/epcn/pdf_files/ manifesto/EPCN-manifesto_english.pdf.

Ferrarese, U. 1983. Chironomidi (Diptera Chironomidae: Tanypodinae). Guide per il riconoscimento delle specie animali delle acque interne italiane. 26. Italy: Consiglio Nazionale per le Ricerche. 67 pp.

Franciscolo, M.E. 1979. Coleoptera (Haliplidae, Hygrobidae, Gyrinidae, Dytiscidae). Fauna d'Italia. Calderini, Bologna. XIV: 8o4 pp.

Füreder, L., R. Ettinger, A Boggero, B. Thaler and H. Thies. 2006. Macroinvertebrate diversity in Alpine lakes: Effects of altitude and catchment properties. Hydrobiologia 562(1): 123-144. doi: 10.1007/s10750-005-1808-7 
Girod, A., M. Bianchi and M. Mariani. 1980. Gasteropodi (Gastropoda: Pulmonata. Prosobranchia: Neritidae, Viviparidae, Bithyniidae, Valvatidae). Guide per il riconoscimento delle specie animali delle acque interne italiane. 7. Italy: Consiglio Nazionale per le Ricerche. 85 pp.

Guareschi, S., C. Gutiérrez-Cánovas, F. Picazo, D. Sánchez-Fernández, P. Abellán, J. Velasco and A. Millán. 2012. Aquatic macroinvertebrate biodiversity: Patterns and surrogates in mountainous Spanish national parks. Aquatic Conservation: Marine and Freshwater Ecosystems 22(5): 598-615. doi: 10.1002/aqc.2256

Kottek, M., J. Grieser, C. Beck, B. Rudolf and F. Rubel. 2006. World Map of the Köppen-Geiger climate classification updated Meteorologische Zeitschrift 15: 259-263. doi: 10.1127/09412948/2006/0130

Lundblad, O. 1967. Die Hydracarinen Schwedens. III. Arkiv för Zoologi 21(1): 1-633.

Maiolini, B., V. Lencioni, A. Boggero, B. Thaler, A. F. Lotter and B. Rossaro. 2006. Zoobenthic communities of inlets and outlets of high altitude Alpine lakes. Hydrobiologia 562(1): 217-229. doi: 10.1007/s10750-005-1812-y

Mazzoldi, P., F. Pederzani, S. Rocchi, A. Schizzerotto and M. Toledo. 2009. La coleotterofauna acquatica del lago di Pratignano (Modena) (Insecta Coleoptera: Haliplidae, Noteridae, Dytiscidae, Helophoridae, Hydrochidae, Hydrophilidae, Sphaeridiidae, Hydraenidae). Atti dell'Accademia Roveveretana degli Agiati 2598(9B): 81-89.

Minelli, A. 1977. Irudinei (Hirudinea). Guide per il riconoscimento delle specie animali delle acque interne italiane. 1. Italy: Consiglio Nazionale per le Ricerche. 42 pp.

Minelli, A. (ed.) 2004. Le torbiere montane - Relitti di biodiversità in acque acide. Quaderni Habitat, 9. Udine: Museo Friulano di Storia Naturale. $156 \mathrm{pp}$.

Moretti, G. 1983. Tricotteri (Trichoptera). Guide per il riconoscimento delle specie animali delle acque interne italiane. 19. Italy: Consiglio Nazionale per le Ricerche. 155 pp.

Moroni, A. 1962. I laghi di Val Panaro. XVI. Roma: Bollettino di Pesca, Piscicoltura e Idrobiologia. $205 \mathrm{pp}$.

Nocentini, A. 1985. Chironomidi 4 (Diptera Chironomidae: Chironominae, larve). Guide per il riconoscimento delle specie animali delle acque interne italiane. 29. Italy: Consiglio Nazionale per le Ricerche. 186 pp.

Novikmec, M., M. Veselská, P. Bitušík, L. Hamerlík, Z. Matúšová, B. R. Klementová and M. Svitok. 2015. Checklist of benthic macroinvertebrates of high altitude ponds of the Tatra Mountains (Central Europe) with new records of two species for Slovakia. Check List 11(1): 1522. doi: 10.15560/11.1.1522

Oertli, B., N. Indermuehle, S. Angélibert, H. Hinden and A. Stoll. 2008. Macroinvertebrate assemblages in 25 high Alpine ponds of the Swiss National Park (Cirque of Macun) and relation to environmental variables. Hydrobiologia 597(1): 29-41. doi: 10.1007/ s10750-007-9218-7

Reice, S. R. and M. Wohlenberg. 1993. Monitoring freshwater benthic macroinvertebrates and benthic processes: measures for assessment of ecosystem health; pp. 287-305, in: D.M. Rosenberg and V.H. Resh (eds.). Freshwater biomonitoring and benthic macroinvertebrates. New York: Chapman \& Hall.

Rivosecchi, L. 1984. Ditteri (Diptera). Guide per il riconoscimento delle specie animali delle acque interne italiane. 28. Italy: Consiglio Nazionale per le Ricerche. 176 pp.

Rocchi, S. 2009. Coleotteri acquatici endemici presenti nell'Ap- pennino settentrionale. Onychium 7: 48-52. http://www. onychium.it/Rocchi_2009

Rossaro, B. 1982, Chironomidi 2 (Diptera Chironomidae: Orthocladiinae). Guide per il riconoscimento delle specie animali delle acque interne italiane. 16. Italy: Consiglio Nazionale per le Ricerche. 79 pp.

Ruggiero, A., A. G. Solimini, and G. Carchini. 2005. The alternative stable state concept and the management of Apennine mountain ponds. Aquatic Conservation: Marine and Freshwater Ecosystems 15(6): 625-634. doi: 10.1002/aqc.749

Sahuquillo, M., J. M. Poquet, J. Rueda and M.R. Miracle. 2007. Macroinvertebrate communities in sediment and plants in coastal Mediterranean water bodies (central Iberian Peninsula). Annales de Limnologie - International Journal of Limnology 43(2): 117-30. doi: 10.1051/limn/2007018

Sala, L., A. Pinca and P. Tongiorgi. 1996. Biotopi umidi dell'alto Appennino modenese e loro batracofauna: un contributo alla conoscenza e alla tutela del territorio del Parco regionale dell'alto Appennino e della sua fauna. Atti della Società dei Naturalisti e Matematici di Modena 125: 123-249.

Solimini, A.G., V. Della Bella and M. Bazzanti. 2005. Macroinvertebrate size spectra of Mediterranean ponds with differing hydroperiod length. Aquatic Conservation: Marine and Freshwater Ecosystems 15(6): 601-611. doi: 10.1002/aqc.747

Solimini, A.G., M. Bazzanti, A. Ruggiero and G. Carchini. 2008. Developing a multimetric index of ecological integrity based on macroinvertebrates of mountain ponds in central Italy. Hydrobiologia 597(1): 109-23. doi: 10.1007/s10750-007-9226-7

Storey, A.W., D.H.D. Edward and P. Gazey. 1991. Surber and kick sampling: a comparison for the assessment of macroinvertebrate community structure in streams of south-western Australia. Hydrobiologia 211(2): 111-121. doi: 10.1007/BFoo037367

Steingruber, S. M., A. Boggero, C. Pradella Caissutti, E. Dumnicka and L. Colombo. 2013. Can we use macroinvertebrates as indicators of acidification of high-altitude Alpine lakes? Bollettino della Società ticinese di scienze naturali 101: 23-34.

Tamanini, L. 1979. Eterotteri acquatici (Heteroptera: Gerromorpha, Nepomorpha). Guide per il riconoscimento delle specie animali delle acque interne italiane. 6. Italy: Consiglio Nazionale per le Ricerche. 105 pp.

Theurillat, J. P. and A. Guisan. 2001. Potential impact of climate change on vegetation in the European Alps: a review. Climatic Change 50: 77-109. doi: 10.1023/A:1010632015572

Viets, K. 1936. Wassermilben oder Hydracarina (Hydrachnellae und Halacaridae) 31: 1-288; 32: 289-574, in: F. Dahl (ed.) Tierwelt Deutschlands, Jena (G. Fischer).

Williams, P., M. Whitfield, J. Biggs, S. Bray, G. Fox, P. Nicolet and D. Sear. 2004. Comparative biodiversity of rivers, streams, ditches and ponds in an agricultural landscape in southern England. Biological Conservation 115(2): 329-341. doi: 10.1016/Sooo63207(03)00153-8

Author contributions: IA and DP collected the data, IA identified the benthic macroinvertebrates. MR prepared the map and the images. IA and MR summarized all the data. MR and RS wrote the text.

Received: 6 August 2015

Accepted: 20 December 2015

Academic editor: Sandra Costa-Böddeker 